ADDIN, Volume 13, Number 1, February 2019

\title{
Developing Value Based Services for Indonesian Microtakaful
}

\section{Achmad Firdaus}

Sekolah Tinggi Ekonomi Islam (STEI) Tazkia, Bogor, Indonesia achmad.firdaus@tazkia.ac.id

\section{Abstract}

Otoritas Jasa Keuangan (OJK) found that the poor and low income people were reluctant to join as insurance participants. OJK has conducted many socialization activities about microinsurance for low-income people which aimed to increase their literacy of insurance. SMES (Sederhana - Mudah - Ekonomis - Segera) services aim to increase insurance inclusion. The study aims to propose a model of value-based service on microtakaful. The service refers to SMES (Sederhana - Mudah - Ekonomis - Segera) and Maslahah Performa value. SMES value to explain the value expected by takaful participants. Maslahah performa to explain the fulfillment of needs to sharia demands by takaful operator. The SMES variable is developed into various sub variables according to SEOJK. Maslahah performa is elaborated to get worship orientation variables and internal process orientation which then be developed into various sub variables. The subvariable weight is determined according to the importance level of each sub variable. The research finds that a value-based microtakaful service model can be derived from the SMES approach and maslahah performa. There is a linkage between the value-based microtakaful service according to participant 
expectation and spirituality and sustainability. The reasearch will contribute to increase literacy of microinsurance.

Keyword: Maslahah Performa, Microtakaful, SMES, Value Based Services.

\section{Abstrak}

MENGEMBANGKAN LAYANAN BERBASIS NILAI BAGI MIKROTAKAFUL INDONESLA. Otoritas Jasa Keuangan (OJK) menemukan bahwa orang miskin dan berpenghasilan rendah enggan bergabung sebagai peserta asuransi. OJK telah melakukan banyak kegiatan sosialisasi tentang asuransi mikro untuk masyarakat berpenghasilan rendah yang bertujuan untuk meningkatkan literasi asuransi. Layanan SMES (Sederhana - Mudah - Ekonomis - Segera) bertujuan untuk meningkatkan inklusi asuransi. Penelitian bertujuan mengusulkan model layanan berbasis nilai pada microtakaful. Layanan mengacu pada nilai SMES (Sederhana - Mudah - Ekonomis - Segera) dan Maslahah Performa. Nilai SMES untuk menjelaskan nilai yang diharapkan oleh peserta takaful. Maslahah Performa untuk menjelaskan pemenuhan kebutuhan oleh operator takaful terhadap tuntutan syariah. Variabel SMES dikembangkan menjadi berbagai sub variabel sesuai dengan SEOJK. Maslahah Performa diuraikan untuk mendapatkan variabel orientasi ibadah dan orientasi proses internal yang selanjutnya dikembangkan menjadi berbagai sub variabel. Bobot sub-variabel ditentukan berdasarkan tingkat kepentingan masing-masing sub variabel. Penelitian menemukan bahwa model layanan takaful mikro berbasis nilai dapat diturunkan dari pendekatan SMES dan Maslahah Perfoma. Ada keterkaitan antara layanan takaful mikro berbasis nilai sesuai harapan peserta dan spiritualitas serta keberlanjutan. Penelitian berkontribusi dalam meningkatkan literasi dan inklusi asuransi mikro.

Kata Kunci: Maslabah Performa, Microtakaful, SMES, Value Based Services. 


\section{A. Introduction}

Ernst and Young ${ }^{1}$ reported the development of takaful in the Middle East and North Africa (MENA). The countries to be observed are the United Arab Emirates, Kingdom of Saudi Arabia, State of Qatar, Egypt, Kingdom of Bahrain, Kuwait and Sultanate of Oman. The penetration of the insurance industry in MENA was growing significantly, although when compared to countries in North America, Europe and Asia, MENA was still lagging behind. The penetration of the insurance industry in the Middle East is Bahrain 2,45\%, UAE 2,35\%, Oman 1,57\%, Qatar 1,54\%, Saudi Arabia 1,51\%, Kuwait 0,90\%, and Egypt 0,68\%.

In Indonesia, Otoritas Jasa Keuangan (OJK) stated that the growth of the insurance sector in Indonesia tends to increase. Figure 1 shows the movement of insurance asset growth to Gross Domestic Product (GDP). Growth rates increase from 2,8\% (2008) to $4,4 \%$ (2013).

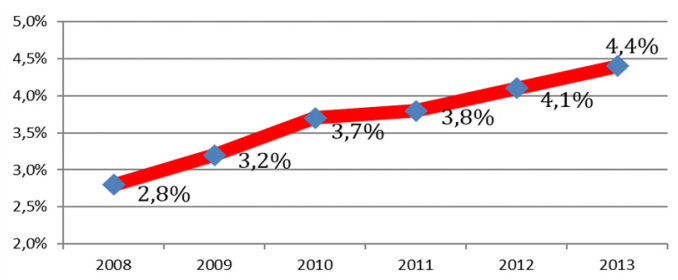

Figure 1

Growth of Insurance Assets to GDP in Indonesia ${ }^{2}$

Figure 2 shows the growth of premiums to GDP. The rate of growth increase from $1,56 \%$ (2008) to 1,83 (2013). There is a decrease in $2013(1,83 \%)$ compared to $2012(1,85 \%)$. However, the overall growth of premiums to GDP from 2008 to 2013 tends to increase. In the study, OJK also noted that half of life insurance companies that have not sold microinsurance products would sell

1 Ernst and Young Global Insurance, Insurance Opportunities in the Middle East, 2017.

2 Otoritas Jasa Keuangan, Catatan Teknis Laporan Tengah Periode Kegiatan Pemantauan dan Evaluasi Asuransi Mikro di Indonesia, 2015. 
microinsurance. While general insurance companies that have not sold microinsurance, states will not sell microinsurance products.

Some of the challenges faced by insurance companies in selling microinsurance products. OJK financial literacy survey in 2013 showed that the level of public understanding of services and insurance services by $18 \%$. This percentage indicates that out of 100 Indonesians, only 18 people understand the products and services offered by insurance companies. However, the low level of Indonesian people's literacy towards insurance also illustrates the high chance of developing insurance in Indonesia. They can be a good market for the insurance industry.

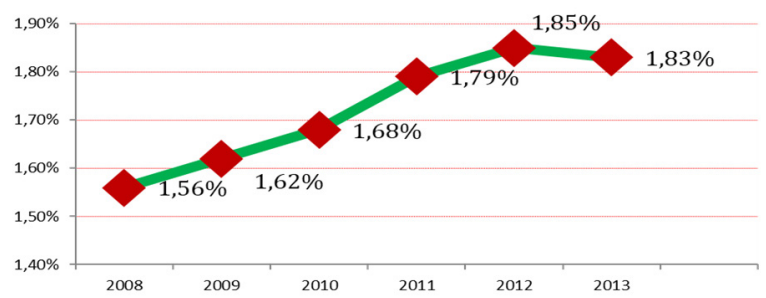

Figure 2

Growth of Insurance Premiums to GDP in Indonesia ${ }^{3}$

The OJK research found that the poor and low-income people were reluctant to join as insurance participants. $89 \%$ of respondents rationalized their decision to the fact that in the event of no claim, the premium paid is lost. $11 \%$ mentioned a variety of reasons, i.e. the compensation is less than the actual requirement, the product is not attractive, the premium is too large, the proof of ownership of the product is not very convincing and there is no automatic renewal option OJK has conducted many socialization activities about microinsurance for low-income people which aimed to increase their literacy of insurance. ${ }^{4}$

3 Otoritas Jasa Keuangan, Catatan Teknis Laporan Tengah Periode Kegiatan Pemantauan dan Evaluasi Asuransi Mikro di Indonesia, 2015.

4 Otoritas Jasa Keuangan, Catatan Teknis Laporan Tengah Periode Kegiatan Pemantauan dan Evaluasi Asuransi Mikro di Indonesia, 2015. 
To increase the poor and low-income people to become microtakaful participants, microtakaful operators must review the objectives of takaful. Takaful is founded not only to gain profit but also to help each other. ${ }^{5}$ This is in line with Altuntas, et al. Altuntas, et al. mentioned that takaful operator in Indonesia could position themselves as a social company or charity company by selling the microtakaful product. This means that the microtakaful product is a medium for takaful operators to carry out the social function of the organization. In this case, the development of microtakaful products is the strategy for developing the social functions of Takaful companies. Takaful operators can run commercial and social functions simultaneously as the company still could earn the profit without neglecting its function as a social organization. ${ }^{6}$

Studies on model of microtakaful services have been conducted by researcher included Giesbert and Steiner, ${ }^{7}$ Pura and Gummerus, ${ }^{8}$ Radermacher and Dercon, ${ }^{9}$ Radermacher and Brinkmann, ${ }^{10}$ Matul, et al. ${ }^{11}$ Gisbert and Steiner described two dimensions of microinsurance values that are unidimensional and multidimensional. Unidimensional value is the assessment of microinsurance participants by considering the benefits to cost. Multidimensional values include functional, emotional, social,

5 Islamic Financial Services Board (IFSB), "Guiding Principles on Governance for Takaful (Islamic Insurance) Undertakings”, 2009.

6 Muhammad Altuntas, Thomas Berry Stolzle, and Anja Erlbeck, "TakafulCharity or Bussiness?: Field Study Evidence from Microinsurance Providers", National Association of Insurance Commissioners, 2011.

7 Lena Giesbert and Susan Steiner, "Client Perceptions of the Value of Microinsurance: Evidence from Southern Ghana", Gemini Life Insurance Company and the Deutsche Gesellschaft für Internationale Zusammenarbeit, 2014.

8 M. Pura and J. Gummerus, "Perceived Value of Mobile Service Use and Its Consequences", Dissertation, Swedish School of Economics and Business Administration Helsinki, 2008.

9 R. Radermacher, H. McGowan, and S. Dercon, "The Impact of Microinsurance", C. Churchill and M. Matul (eds.), Microinsurance Compendium, Volume 2 (Munich: ILO with Geneva and Munich Re Foundation, 2012).

10 Ralf Radermacher and Johannes Brinkmann, "Insurance for the Poor?: First Thoughts about Microinsurance Business Ethics", Journal of Business Ethics 103, Supplement 1, 2011: 63-76.

11 Michal Matul, Clemence Tatin-Jaleran, and Eamon Kelly, "Improving Client Value from Microinsurance Insights from India, Kenya, and the Philippines", September 2011. 
epistemic and conditional dimensions. Sánchez, et al. identified the emotional, social and four types of functional values of installation, professionalism, quality and price.

Pura and Gummerus analyzed the value of mobile services. There were six dimensions of value; they are conditional, epistemic, emotional, social, monetary, and value convenience. ${ }^{12}$ Radermacher and Dercon described the value of microinsurance clients from the outcome. ${ }^{13}$ The impact is evidence of value. The impact of this research is to know whether microinsurance improves the welfare of low-income households or not. The impact is the point of view of results. However, it is still important to consider intermediary steps such as understanding when, how, and why impacts occur.

Matul, et al. developed a framework of value-based services for microinsurance participants. Values are understood as mental concepts at a higher level of benefits and sacrifices. Values are often measured empirically by simple indicators of what clients perceive. The value of ILO services is known as the Product - Access Cost - Experience approach or PACE. ${ }^{14}$ PACE is a tool to assess the value of microinsurance products related to the provision of similar risk protection. Product deals with benefits, service quality, exceptions, and waiting periods. Access relates to participants' access to microinsurance products. Cost related to the cost of premiums and other costs. Experience is related to the experience found by microinsurance participants, especially regarding claims payments, policy administration as well as customer service.

In line with PACE, OJK described value services with the SMES approach. SMES is short for "Sederhana", "Mudah",

12 M. Pura and J. Gummerus, "Perceived Value of Mobile Service Use and Its Consequences", Dissertation, Swedish School of Economics and Business Administration Helsinki, 2008.

13 R. Radermacher, H. McGowan, and S. Dercon, "The Impact of Microinsurance", C. Churchill and M. Matul (eds.), Microinsurance Compendium, Volume 2 (Munich: ILO with Geneva and Munich Re Foundation, 2012).

14 Michal Matul, "PACE to Improve Client Value", Microinsurance Innovation Facility International Labour Organization, 2011. 
"Ekonomis", and "Segera". "Sederhana" deals with microinsurance products. ${ }^{15}$ Microinsurance products are insurance products designed to protect the low-income communities from the financial risk. "Mudah" implies the easiness of low-income people to access microinsurance products. "Ekonomis" deals with the premium cost for a microinsurance product. "Segera" related to the prompt claim payment process.

Khan stated that microtakaful is a mechanism that provides sharia-based protection for the poor and disadvantaged individuals at an affordable price. ${ }^{17}$ Compliance with the requirement is not only from the perspective of microtakaful participants but also from maqasid asy-syariah. Maslahah performa described the basic needs of sharia-based organizations that are worship orientation, internal process orientation, talent orientation, learning orientation, customer orientation, and wealth orientation. ${ }^{18}$

The study is conducted with the aim of creating a model of value-based services on microtakaful to participants. Service refers to SMES and Maslahah Performa value. SMES value to explain the value expected by takaful participants. Maslahah performa to explain the fulfillment takaful operator needs to sharia demands.

The Research to develop a model of value-based microtakaful service. The framework of research refers to SMES and maslahah performa. ${ }^{19}$ SMES is the approach used by OJK to develop microinsurance. Maslahah performa is the concept of Islamic organizations based on maslahah. The element of maslahah is very important for takaful as a charitable and commercial organization. The framework of research as Figure 5.

15 Otoritas Jasa keuangan (OJK), Grand Design Pengembangan Asuransi Mikro Indonesia, 2013.

16 Otoritas Jasa keuangan (OJK), Peraturan Otoritas Jasa Kenangan Nomor $23 /$ Pojk.05/2015 Tentang Produk. Asuransi dan Pemasaran Produk, Asuransi, 2015.

17 Akhtar J. Khan. "Microtakaful: The Way Forward", 2006.

18 Achmad Firdaus and Ahmad Mukhlis Yusuf, "Maslahah Performa: Maslahah Based Organization", Paper, Presented on $4^{\text {th }}$ ISRA International Colloquium for Islamic Finance (IICIF) 2014, Kualalumpur, Malaysia, September 3-4, 2014.

19 Firdaus and Yusuf. 


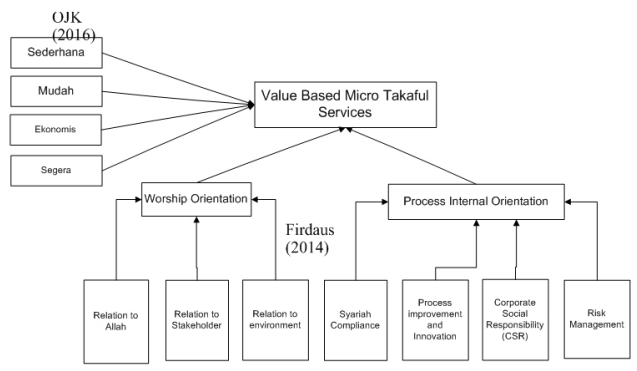

Figure 4

The Framework of Value-Based Microtakaful Service

The SMES variable is developed into various sub variables according to SEOJK No. 9/SEOJK.05/2017. Worship orientation is variable that explain the spirituality of takaful operators. Internal process orientation is variable that explain the sustainability of takaful operator. Worship orientation and internal process orientation are developed into various sub variables according to maslahah performa approach. The weight of the variable is determined according to the level of importance to each sub variable. The assessment score for each variable refer to Matul and Kelly, ${ }^{20}$ as per Table 3.

\section{B. Discussion}

\section{Microtakaful: Definition and Product}

Takaful in Arabic is a form of the noun that cannot be calculated. Takaful is derived from the root of the word kafala that means giving a guarantee. The main characteristic of takaful is al-musyarakah which means sharing. Takaful means sharing responsibility or sharing collateral together. Takaful from the economic perspective implies the mutual assurance provided to a group of people living in the same social with regard to the risk of a person's life, property or other that have valuable possessions. ${ }^{21}$

20 Michal Matul and Eamon Kelly, "How to Conduct a PACE Client Value Assessment: a Technical Guide for Microinsurance Practitioners", January 2012.

21 Mohd Ma'sum Billah, Applied Takaful and Modern Insurance: Law and Practice (Selangor: Thomson Sweet and Maxwel Asia, 2007). 
Constitution No. 40/2014 stated that takaful is a collection of agreements consisting of agreements between sharia insurance companies and policyholders and agreements among policyholders, in the context of the management of contributions based on sharia principles to help and protect each other.

Fiqh Academy in Mecca in 1985 concluded that the insurance is haram because the contract of profit insurance has elements of gharar and maysir that make it is not compliance to sharia. Halal insurance must meet these conditions: First, the nature of insurance is cooperation which means insurance must follow the model of cooperative or mutual. Secondly, risk pooling should be done on the basis of charity and cooperation. ${ }^{22}$

Altuntas, et al. observed various charitable practices on insurance. In his research, he found that the insurance carries out activities of empowerment, social, active in tackling the impact of natural disasters, etc. Based on the definition and operational practice of takaful, the goal of Takaful is not merely to create profit but to help each other or charity. ${ }^{23}$

Microinsurance defined as insurance products intended for low-income people with simple features and administration, easy to obtain, economical price, and quick in settlement of the claim. Lowincome people according to OJK are people with monthly income no more than Rp 2.500.000. Then, OJK developed SMES approach for microinsurance product. ${ }^{24}$

Microtakaful operators are insurance companies that organize microinsurance products where in the implementation of its activities either all or part of its business is run with the principles of sharia. The microtakaful is a risky product of adherence to sharia,

22 Zainal Abidin Mohd Kassim, "Micro Takaful or Micro Insurance", Takaful and Mutuality, Issue 2, February 2014: 12-14.

23 Muhammad Altuntas, Thomas Berry Stolzle, and Anja Erlbeck, "TakafulCharity or Bussiness?: Field Study Evidence from Microinsurance Providers”, National Association of Insurance Commissioners, 2011.

24 Otoritas Jasa Keuangan (OJK), Grand Design Pengembangan Asuransi Mikro Indonesia, 2013; Otoritas Jasa Keuangan (OJK), Catatan Teknis Laporan Tengah Periode Kegiatan Pemantauan dan Evaluasi Asuransi Mikro di Indonesia, 2015. 
designed appropriately for low-income segments at affordable prices, appropriate shipping and delivery mechanisms. The difference between takaful and microtakaful is in Table 1. Microinsurance products in Indonesia is described in Table 2. While, microtakaful products in Indonesia is described in Table 3.

\section{Product - Acces - Cost - Experience (PACE)}

The PACE is a value-based analytics tool for microinsurance participants developed by the ILO. PACE is used to assess microinsurance products as an alternative provider of risk protection. Matul and Kelly explained that the value of participants as intended by PACE aims to reduce vulnerability to risk management practices and aim to improve the well-being of participants. ${ }^{25}$

PACE emphasizes added value for participants of microinsurance by comparing one product with another product, including informal mechanisms and social security schemes. In this case, the scheme of informal mechanisms and social security becomes a benchmark to assess microinsurance products.

"Product" illustrates compliance with coverage considerations, benefits levels, eligibility criteria, and the availability of valueadded services. "Access", focuses on accessibility and simplicity by investigating options, registration, information, education, premium payment methods and proximity. "Cost", measures the affordability and value of money, as well as additional costs to keep the overall cost of delivery. "Experience", assess response and simplicity by looking at claims procedures and processing times, policy administration, products, and customer service.

Matul and Kelly described the three stages to be performed on the PACE analysis. The three stages are preparation, application and communication, and action. The preparation stage consists of 3 steps: agree on the objectives and scope of the analysis, develop

25 Michal Matul and Eamon Kelly, "How to Conduct a PACE Client Value Assessment: a Technical Guide for Microinsurance Practitioners", January 2012. 
a work plan and collect, and organize the data. The application stage consists of 4 steps: analyzing data and identifying information gaps, collecting additional data, compiling information and performing analysis, benchmarking and calculating scores. Stages of communication and action consist of 3 steps: sharing the results, collecting and inputting feedback, brainstorming implications and developing activity plans and analyzing documents, outcomes and actions. ${ }^{26}$

The three main functions of PACE are to identify opportunities to increase the value of participants, conduct competitor analysis at the country level and balance the value of participants against strategic business choices. The value creation cycle of participants according to Matul and Kelly as Figure 3. ${ }^{27}$

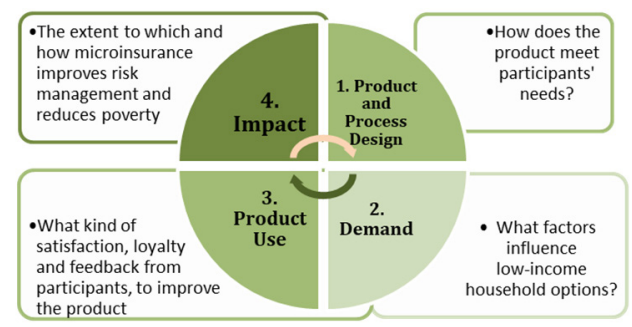

Figure 3

Frame Work of PACE

Altuntas, et al. conducted a microtakaful market research in Indonesia. They analyzed insurance that aims to be purely business (conventional insurance) and insurance that aims to charity (takaful). The two insurance companies that are the object of the Altuntas, et al. case study are Takaful Indonesia (full-fledged takaful) and conventional international insurance companies operating in the window system. Altuntas' findings show that although takaful has the goal of mutual help but can also benefit. Conversely, conventional insurance companies can also successfully enter the microtakaful

26 Matul and Kelly.

27 Matul and Kelly. 
market in developing countries. ${ }^{28}$

Matul, et al. and Matul and Kelly described 5 participants' preferences for microinsurance services: responsive, simple, appropriate, accessible, affordable. Responsive is to provide the timely response through fast and accurate claim settlement to the participants so that the poor do not need to take the expensive and reliable way of borrowing on loan sharks. Simple is easy to understand and is used as a whole principle in the design of microinsurance products provided to people with low literacy. Suits is available with the needs of risk management of the targeted population. Accessible is providing easy access to products that described in simple language and delivered to the target group. Affordable is providing value for money at the price where the target audience even with limited paying capacity, they are still able to pay. ${ }^{29}$

Matul, et al. analyzed 15 microinsurance schemes in several countries using PACE. Matul reviewed the collection of products in Kenya; it was found that the list of required documents was often too long. It is unclear whether additional documents contribute to corporate controls, but clearly, this condition makes a bad experience for customers. In fact, the process can be simplified by reducing document requirements for the verification process. The Policy is possible by using a Village Head certificate within 24 hours. The Philippines looks no question about the value of the product. In India, microhealth insurance products look half way. Matul feels the importance of governmentsponsored initiatives. There is an interesting dynamic between community-based value offerings and private schemes. ${ }^{30}$

28 Muhammad Altuntas, Thomas Berry Stolzle, and Anja Erlbeck. "Takaful Charity or Bussiness?: Field Study Evidence from Microinsurance Providers", National Association of Insurance Commissioners, 2011.

29 Michal Matul, Clemence Tatin-Jaleran, and Eamon Kelly, "Improving Client Value from Microinsurance Insights from India, Kenya, and the Philippines", September 2011; Michal Matul and Eamon Kelly, "How to Conduct a PACE Client Value Assessment: a Technical Guide for Microinsurance Practitioners", January 2012.

30 Michal Matul, Clemence Tatin-Jaleran, and Eamon Kelly, "Improving Client Value from Microinsurance Insights from India, Kenya, and the Philippines", September 2011. 
Kecek and Akinci conducted a study on the use of quality function deployment (QFD) on insurance. Characteristics of customer requirements: price, payment, reliability, customer relationship, technology and policy. While the service characteristics of each customer requirement are the price (reasonable price), payment (refund payment in a short time, easy form of policy payment), reliability (honest policy, popularity), customer relationship (agent behavior, corporate behavior after damage), technology (technological infrastructure) and physical (physical form of policy). ${ }^{31}$

\section{Sederhana - Mudah - Ekonomis - Segera (SMES)}

SMES as described in SE OJK No. 9/SEOJK.05/2017 which stands for sederhana, mudah, ekonomis and segera. "Sederhana" that is microinsurance products should meet:

a. Microinsurance products provide basic protection benefits over one type or more of the risks facing low-income communities;

b. Microinsurance products have a simple policy.

c. Microinsurance products have simple administration features and processes.

"Mudah" is micro-insurance products have the ease of: products are easily available in low-income communities through channels distribuiton of microinsurance products. Secondly, the company is easily contacted by policyholders, insured, participants, and / or other parties in order to obtain information about insurance products and/or make claims.

"Ekonomis" i.e. microinsurance product has a relatively affordable premium or contribution for low-income communities. The risk premium or risk contribution of the microinsurance product is at least $50 \%$ of the gross premium or gross contribution.

31 Gulnur Kecek and Omer Can Akinci, "Quality Function Deployment and an Palication in an Insurance Company", International Jurnal of Academic Reserach in Business and Social Sciences, Vol. 6, No. 4, 2016. 
Sum assured of microinsurance product at most 24 times higher UMP at the time of closing of Insurance Policy.

"Segera" i.e. microinsurance product has features:

a. Applicable immediately after the activation or registeration of membership is approved by the company and the premium / contribution is paid in full;

b. The company must provide confirmation to the policyholder, the insured, or the participant immediately after the membership is approved by the company;

c. Waiting period of 30 days from activation or membership registeration approved by the company;

d. In products that have a waiting period, the insurance policy stipulates that insurance benefits may be granted if a disaster or risk occurs after the waiting period;

e. The process of payment of insurance benefit, no later than 10 working days from the time the company receives the claim documents required in the insurance policy completely and correctly.

\section{Maslahah Performa}

Maslahah performa is a performance management system used by maslahah based organizations. For achieving the benefit sustainability, the organization must meet basic needs. Basic needs of the organization consists of worship orientation. It is the need to protect and to maintain religion in the life of the organization. Internal process orientation is the need to protect and to maintain the soul of the organization. Talent orientation is the need to protect and to maintain talent of the organization. Learning orientation is the need to protect and to maintain intellect of the organization. Customer orientation is the need to protect and to maintain customer satisfaction. Wealth orientation is the need to protect and to maintain the wealth of organization. ${ }^{32}$

32 Achmad Firdaus and Ahmad Mukhlis Yusuf, "Maslahah Performa: Maslahah Based Organization", Paper, Presented on $4^{\text {th }}$ ISRA International Colloquium for Islamic Finance (IICIF) 2014, Kualalumpur, Malaysia, September 3-4, 2014. 
Worship orientation is essentially the implementation of three aspects of Islam, namely aqidah, shariah and akhlak by the organization to Allah, stakeholders, and environment. The organization's internal process orientation is identified in core processes, support processes, compliance processes, regulatory compliance processes, improvement and innovation processes, strategic processes and sustainability, CSR processes, risk management processes and disaster management processes and emergencies.

\section{Developing Weigthed and Rating of Services}

Matul and Kelly proposed systematics assessment of participants microinsurance services. Four variables namely P-AC-E, each has 4 sub variables. So PACE has a total of 16 sub variables. Each sub variable has different weights. Two main sub variables have a larger weight of $70 \%$. While the other 2 sub variables have a smaller weight, which is $30 \%$. So that the weight for each sub variables set by Matul and Kelly that: sub varibel 1 has weight 35\%, sub sub varibel 2 has a weight of $35 \%$, sub varibel 3 has a weight of $15 \%$, sub varibel 4 has a weight of $15 \%$ (Table 4 ). ${ }^{33}$

Each sub variable is assessed by score between 1 and 5. Each is explained by the criteria as Table 5 .

SMES is developed into several sub variables. The "simple" variable becomes 3 sub variables. The "simple" variable becomes 2 sub variables. The "economic" variable become 2 sub variables. The "economic" variable becomes 6 sub variables. Completely is as Table 6.

Weight of each sub variable is determined refers to Matul and Kelly that is determined based on the sub-variable importance level for the takaful micro participant. In the "simple" variable, "basic protection benefits" sub variable and "simple insurance policies" have the same level of importance but both sub-variables

33 Michal Matul and Eamon Kelly, "How to Conduct a PACE Client Value Assessment: a Technical Guide for Microinsurance Practitioners”, January 2012. 
have a higher level of importance than the "simple features and administrative processes" sub-variables. Weight of "basic protection benefits" and "simple insurance policy" sub-variable are determined by $40 \%$. While "features and simple administrative process" sub variable is determined by $20 \% .^{34}$

In the "easy" variable, "easy to obtain" and "easy to contact" sub variables are equal importance. Microtakaful products should be easily obtained by prospective participants. Attempts to bring microtakaful product to potential participants are much more difficult than takaful product. Difficulty in contacting a microtakaful operator will have an impact on the participants' bad experiences. So both variables have a weight of $50 \%$.

In the "economical" variables, "affordable contributions" and "cash benefits at most $24 \mathrm{x}$ UMP" sub-variables have the same level of importance. Microtakaful products are designed for lowincome communities. As stated OJK, the low-income group is the community who have income per month $<$ Rp 2.500.000,-. Of course, contributions greatly influence the decision of prospective participants to join with takaful. While the value of covered associated with UMP amount, also become part of the consideration of prospective participants to join with takaful. Both sub variables have the same importance level, each of $50 \%$.

In the "immediate" variable, "as soon as activation or application is approved", "the wait period is 30 days", "the provision of covered may be given if the risk occurs after the waiting period", "the longest paymnet is 10 days" sub variable which are higher than "confirmation as soon as the registeration is approved", and "disputes are settled in accordance with legislation" sub variable. Based on experience, confirmation is not a barrier, either for participation registeration or for claim submission process. As technically, sometimes at the time of participation confirmation process, there is a problem of communication network. Disputes between takaful operators and

34 Michal Matul and Eamon Kelly, "How to Conduct a PACE Client Value Assessment: a Technical Guide for Microinsurance Practitioners", January 2012. 
takaful participants for micro-products are rare. This is considering the value of the benefits of micro products is quite small. The first four sub-variables each weighed $20 \%$. While the other 2 sub variables, each has a weight of $10 \%$.

Maslahah performa developed into several sub variables. Variable of worship orientation becomes 3 sub variables. Variable internal process orientation into 2 sub variables. Completely as Table 7.

Firdaus and Yusuf stated that the basic needs of organizations must be met by the organization in a balanced way. This means that each sub variable in the worship orientation variable has the same importance level. So that the weight for "organizational interaction with Allah", "organizational interaction with stakeholders", and "organizational interaction with the environment" sub variables amounted to $1 / 3$ or $33.3 \%$. Each sub variable in the internal process orientation variable has the same importance level. So that the weight for "compliance sharia", "process improvement and innovation", "corporate social responsibility (CSR)", and "risk management" sub variable each of $25 \% .{ }^{35}$

Score is determined refers to Table 3. That are:

a. Ineffective and not appropriate for the participants' needs. If the assessment was found sub-variables are not applied or applied but not ineffectively or inappropriately;

b. Widened and not specific to participants' needs. If the appraisal is found sub variables are applied but not specific to the participants;

c. Quite effective and useful for participants. If the assessment was found sub variables applied quite effective and useful for participants;

d. Effective in some situations. If the assessment was found sub-variables have been applied effectively in some situations;

35 Achmad Firdaus and Ahmad Mukhlis Yusuf, "Maslahah Performa: Maslahah Based Organization", Paper, Presented on $4^{\text {th }}$ ISRA International Colloquium for Islamic Finance (IICIF) 2014, Kualalumpur, Malaysia, September 3-4, 2014. 
e. Effective in almost all situations. If the assessment was found sub-variables have been applied effectively in various situations.

Next is calculated sub total valuation which is multiplication of weight with value. The total value is obtained by summing all the values of each sub variable. In mathematical equations it is written as:

$$
\begin{aligned}
& \text { Total Value }=\sum_{i=1}^{n} \mathrm{Si} x \mathrm{Ni} \quad+\sum_{i=1}^{n} \mathrm{Mi} \times \mathrm{Ni} \quad+ \\
& \sum_{i=1}^{n} E i \times N i \\
& +\sum_{i=1}^{n} \mathrm{Wi} \times \mathrm{Ni}+\sum_{i=1}^{n} \mathrm{Ii} \times \mathrm{Ni}+\sum_{i=1}^{n} \mathrm{Pi} \times \mathrm{Ni} \\
& \text { S : Weight of "Sederhana" Variable } \\
& \text { M : Weight of "Mudah" Variable } \\
& \text { E : Weight of "Ekonomis" Variable } \\
& \text { W : Weight of "Segera" Variable } \\
& \text { I : Weight of "Worship Orientation" } \\
& \text { P : Weight of "Process Internal Orientation" } \\
& \text { i : Sub variable form } \mathrm{i} \text { to } \mathrm{n} \\
& \mathrm{Ni} \quad \text { : Score (from } 1 \text { to } 5 \text { ) }
\end{aligned}
$$

\section{Conclusion}

A value-based microtakaful service model can be derived from the SMES and maslahah performa approach. Obtained linkages between the value-based microtakaful service according to participant expectation and spirituality and sustainability. The mathematics equation used is:

$$
\begin{aligned}
& \text { Total Value }=\sum_{i=1}^{n} \mathrm{Si} \times \mathrm{Ni}+\sum_{i=1}^{n} \mathrm{Mi} \times \mathrm{Ni}+ \\
& \sum_{i=1}^{n} \mathrm{Ei} \times \mathrm{Ni} \\
& +\sum_{i=1}^{n} \mathrm{Wi} \times \mathrm{Ni}+\sum_{i=1}^{n} \mathrm{Ii} \times \mathrm{Ni}+\sum_{i=1}^{n} \mathrm{Pi} \times \mathrm{Ni}
\end{aligned}
$$


SMES is an assessment of microtakaful operator services from participant expectation perspective. However, it is important to assess spirituality and sustainability aspects of microtakaful operators. Spirituality needs to be measured to assess the motivation and background of the services provided by microtakaful operators. Sustainability needs to be measured to ensure that even with smaller profits, microtakaful operators can sustain. Some further research needs to be done to find out whether there is an influence of spirituality and sustainability on increasing value-based services by microtakaful operators to participants. 


\section{REFERENCES}

Altuntas, Muhammad, Thomas Berry Stolzle, and Anja Erlbeck. "Takaful-Charity or Bussiness?: Field Study Evidence from Microinsurance Providers", National Association of Insurance Commissioners. 2011.

Billah, Mohd Ma'sum. Applied Takaful and Modern Insurance: Law and Practice. Selangor: Thomson Sweet and Maxwel Asia, 2007.

Ernst and Young Global Insurance. Insurance Opportunities in the Middle East. 2017.

Firdaus, Achmad and Ahmad Mukhlis Yusuf. "Maslahah Performa: Maslahah Based Organization", Paper, Presented on $4^{\text {th }}$ ISRA International Colloquium for Islamic Finance (IICIF) 2014, Kualalumpur, Malaysia, September 3-4, 2014.

Giesbert, Lena and Susan Steiner. "Client Perceptions of the Value of Microinsurance: Evidence from Southern Ghana", Gemini Life Insurance Company and the Deutsche Gesellschaft für Internationale Zusammenarbeit. 2014.

Hasim, Haslifah Mohamad. "Microtakaful as an Islamic Financial Instrumen for Poverty Alleviation in Iraq", Middle-East Journal of Scientific Research 21, No. 12, 2014: 2.315-2.325.

Islamic Financial Services Board (IFSB). "Guiding Principles on Governance for Takaful (Islamic Insurance) Undertakings”. 2009.

Kecek, Gulnur and Omer Can Akinci. "Quality Function Deployment and an Palication in an Insurance Company", International Jurnal of Academic Reserach in Business and Social Sciences, Vol. 6, No. 4, 2016.

Kassim, Zainal Abidin Mohd. "Micro Takaful or Micro Insurance", Takaful and Mutuality, Issue 2, February 2014: 12-14.

Khan, Akhtar J. "Microtakaful: The Way Forward”. 2006.

Matul, Michal and Eamon Kelly. "How to Conduct a PACE Client Value Assessment: a Technical Guide for Microinsurance 
Practitioners", January 2012.

Matul, Michal, Clemence Tatin-Jaleran, and Eamon Kelly. "Improving Client Value from Microinsurance Insights from India, Kenya, and the Philippines”, September 2011.

Matul, Michal. "PACE to Improve Client Value", Microinsurance Innovation Facility International Labour Organization, 2011.

Pura, M. and J. Gummerus. "Perceived Value of Mobile Service Use and Its Consequences", Dissertation, Swedish School of Economics and Business Administration Helsinki, 2008.

Otoritas Jasa keuangan (OJK). Grand Design Pengembangan Asuransi Mikro Indonesia. 2013.

- Catatan Teknis Laporan Tengah Periode Kegiatan Pemantauan dan Evaluasi Asuransi Mikro di Indonesia. 2015.

- Peraturan Otoritas Jasa Kenangan Nomor 23/Pojk.05/2015

Tentang Produk Asuransi dan Pemasaran Produk Asuransi. 2015.

- Mengurangi Kerentanan Ekonomi Melalui Asuransi Mikro: Tantangan dan Potensi di Indonesia. 2015.

. Surat Edaran Otoritas Jasa Keuangan No. 9/SEOJK.05/2017 Tentang Produk Asuransi Mikro dan Saluran Pemasaran Produk Asuransi Mikro. 2017.

Radermacher, Ralf and Johannes Brinkmann. "Insurance for the Poor?: First Thoughts about Microinsurance Business Ethics", Journal of Business Ethics 103, Supplement 1, 2011: 63-76.

Radermacher, R., H. McGowan, and S. Dercon. "The Impact of Microinsurance", C. Churchill and M. Matul (eds.), Microinsurance Compendium, Volume 2. Munich: ILO with Geneva and Munich Re Foundation, 2012. 
Achmad Firdaus 